\title{
The histopathological predictor factors in the recurrence of cervical carcinoma stage IB - IIA after radical hysterectomy
}

\author{
Deri Edianto ${ }^{*}$ Emil Taufik ${ }^{\dagger}$, M. Farid Aziz ${ }^{\#}$
}

\begin{abstract}
Abstrak
Penelitian ini dilakukan untuk mengetahui angka kejadian (insidens) kekambuhan kanker serviks stadium IB - IIA pasca histerektomi radikal dan faktor-faktor yang mempengaruhinya. Penelitian bersifat kohort retrospektif untuk melihat kekambuhan kanker serviks stadium IB - IIA yang dihisterektomi radikal pada 68 penderita. Akan tetapi pemeriksaan ulang histopatologik hanya dilakukan pada 58 kasus yang memenuhi kriteria penelitian. Terhadap 58 kasus ini dilakukan pemeriksaan ulang histopatologik yang meliputi penilaian tipe histopatologik, diferensiasi, sebukan sel radang, invasi ke parametrium, limfe-vaskuler, sayatan vagina, endometrium dan kelenjar getah bening (KGB), serta kedalaman invasi stroma. Insidens kekambuhan dalam waktu dua tahun pasca histerektomi radikal 30,8\% atau 21 dari 68 kasus. Sembilan (75\%) dari 12 kasus dengan invasi KGB mengalami kekambuhan dibanding 10 $(21,7 \%)$ dari 46 kasus tanpa invasi $K G B(P=0,0004)$. Dari 11 kasus dengan karsinoma adenoskuamosa, 8 diantaranya mengalami kekambuhan $(P=0,01)$. Selain itu, hanya satu dari 12 kasus dengan kedalaman invasi stroma <5 mm yang mengalami kekambuhan, dibanding 18 kekambuhan dari 45 kasus dengan kedalaman invasi stroma $>5 \mathrm{~mm}(P=0,02)$. Secara statistik faktor-faktor klinik seperti paritas, stadium, dan besar lesi tidak mempengaruhi kekambuhan secara bermakna, demikian pula dengan faktor patologik lainnya, seperti diferensiasi, sebukan sel radang, invasi ke parametrium, limfe-vaskuler, sayatan vagina dan endometrium. Pada insidens kekambuhan pasca histerektomi radikal dalam 2 tahun pertama, faktor risiko patologik yang berpengaruh adalah invasi $K G B$, karsinoma adenoskuamosa, dan kedalaman invasi stroma. (Med J Indones 2001; 10: 79.83)
\end{abstract}

\begin{abstract}
The aim of this study is to know the incidence of cervical carcinoma stage IB - IIA recurrence after radical hysterectomy and the histopathologic factors which are related to it. This was a retrospective cohort study involving 68 patients with recurrence cervical carcinoma stage IB - IIA who underwent radical hysterectomy. However, there were only 58 cases which fulfilled the study criteria, and therefore were evaluated histopathologically. The histopathologic evaluation consisted of differentiation, inflammatory reaction, lymph-vascular permeation, invasion to the vagina incision margin, and to endometrium, lymph nodes metastasis, and the depth of stromal invasion. The incidence of the cervical carcinoma stage IB - IIA recurrence 2 years after radical hysterectomy was $30.8 \%(21$ out of 68 cases). The recurrence occurred in nine (75\%) out of 12 cases with lymph node metastasis, compared to $10(21.7 \%)$ out of 46 cases without lymph node metastasis $(P=0.0004)$. In addition, eight out of 11 adenosquamous carcinoma cases had recurrence $(P=$ 0.01 ). There was only one out of the 12 cases with the depth of stromal invasion of $<5 \mathrm{~mm}$ that had recurrence compared to 18 out of 45 cases with stromal invasion of $>5 \mathrm{~mm}(P=0.02)$. The clinical factors such as parity, staging, size of the tumor were not statistically significant. The other pathologic factors such as differentiation, inflammatory reaction, and parametrial, vagina incision margin and endometrial invasion were not statistically significant. The incidence of the recurrence of cervical carcinoma within 2 years after hysterectomy was related to the pathological risk factors i.e. lymph node metastasis, adenosquamous cell carcinoma and. the depth of stromal invasion. (Med J Indones 2001; 10: 79-83)
\end{abstract}

Keyword: risk factor, cervical cancer

\footnotetext{
* Department of Obstetrics and Gynecology, Adam Malik Hospital Medan, Training in Gynecologic - Oncology Division, Department of Obstetrics and Gynecology, Faculty of Medicine, University of Indonesia / Dr. Cipto Mangunkusumo Hospital Jakarta, Indonesia

${ }^{\dagger}$ Department of Pathology, Faculty of Medicine, University of Indonesia / Dr. Cipto Mangunkusumo Hospital Jakarta, Indonesia

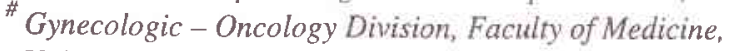
University of Indonesia / Dr. Cipto Mangunkusumo Hospital Jakarta, Indonesia
}

The improvement in awareness and education of the people about cervical cancer tends to increase the detection of the disease in early stage and in younger age, and also to increase the operative management rather than radiation to maintain the hormonal function.

However, the incidence of recurrence after radical hysterectomy is still about $10-20 \%$. Almost all the recurrent patients ceased within a year. Therefore, adjuvant radiotherapy or chemotherapy is advocated 
for high risk cases to reduce the recurrence rate. There were some factors considered in giving adjuvant radiotherapy or chemotherapy, such as lymph node metastases, lymph vascular permeation, parametrial invasion, invasion to the margin of the vagina incision, invasion to endometrium, histopathologic type, differentiation, the depth of stromal invasion, etc. $^{1-13}$

The aim of this study is to know the incidence of cervical carcinoma stage IB - ILA recurrence after radical hysterectomy and the histopathologic factors which are related to it.

\section{METHODS}

This retrospective cohort study was conducted in Cipto Mangunkusumo Hospital, involving patients who underwent radical hysterectomies for cervical carcinoma stage IB - IIA, from January 1992 to December 1995.

\section{Inclusion criteria}

- $\quad$ Cervical cancer stage IB - IIA

- First therapy was radical hysterectomi

- With / without post surgery adjuvant therapy.

- At least came for follow up at the $24^{\text {th }}$ month post surgery when there was no reccurence.

- The aim of radical surgery was reached macroscopically and microscopically.

- When the aim of radical surgery was not reached, at least there was a clinically or microscopically tumor free period after adjuvant therapy.

\section{Exclusion criteria}

- Medical record was not found

- Got neoadjuvant therapy before radical surgery

- Reevaluation of histopathologic slide cannot be done (missing or damaged slide)

- Preparation to surgery and/or follow up were not done in RSCM.

Follow up was done each time the patient came until the last follow up (at the $24^{\text {th }}$ month).

Adjuvant therapy was given when a condition below was found i.e.:

- histopathological finding: adenocarcinoma

- lymph - vascular permeation

- the border of incision was not tumor free

- pelvic lymph node invasion
- parametrium invasion

- poor differentiation

The adjuvant therapies given were pelvic irradiation, chemoradiation (using $\mathrm{MMC}+5 \mathrm{FU}$ ) or chemotherapy alone: The type of the adjuvant therapy given was based on the ASEAN trial on carcinoma of the cervix protocol at that time. Each of the cases that fulfilled the criteria received an adjuvant therapy, and the therapy was chosen randomly.

The medical record of the patients were reviewed and the data collected were: age, education, occupation, parity, stage of carcinoma and tumor size. The pathologic slides were reexamined to see the histopathologic type, differentiation, the inflammatory cell reaction, the depth of cervical stromal invasion, parametrial invasion, invasion to endometrium, lymph vascular permeation, pelvic lymph node metastasis, and invasion to the margin of vagina incision.

The data was analyzed in the department of community medicine, Faculty of Medicine, University of Indonesia, to recognize the risk factors for the recurrence of the disease.

\section{RESULT}

There were 108 cases of cervical cancer stage IB - IIA that underwent radical hysterectomies from January 1992 to December 1995. However, the evaluation of the medical record and reexamination of the surgical specimen histopathologically showed that only 94 cases matched to cervical cancer stage $\mathbb{B}$ - ПA.

\section{Age, parity, and occupation}

The mean of the patients age was 38.8 (SD 65) years old and the median was 38 years old. The youngest was 28 years old, and the oldest was 56 years old. The parity varied between $0-9$. However, most of the patients (27.6\%) had parity 4. Most of the patients $(82.8 \%)$ were house-wives and the rest (17.2\%) were labourer. Parity, staging and tumor size were not statistically significant in increasing the incidence of recurrence.

\section{Histopathologic type}

During that period, there were 68 cases which were followed up to 24 months post operatively, but there were only 58 cases which fulfilled the inclusion criteria and were evaluated histopathologically. The 
distribution of histopathologic profile according to the recurrence is shown in Table 1.

Twenty one $(30.8 \%)$ out of 68 cases which were followed up to 24 months post operatively, with or without adjuvant therapy, had recurrent carcinoma.

Eight out of 11 adenosquamous carcinoma cases had recurrence within 24 months, and there were 2 additional recurrent cases after 25 months. The rest 1 case was well controlled until 57 months of follow up.

Table 1. The distribution of histopathologic profile according to the recurrence

\begin{tabular}{|c|c|c|c|}
\hline Histopathologic profile & No recurrence & Recurrence & $P$ Value \\
\hline Histology & & & 0.01 \\
\hline Squamous & 19 & 7 & \\
\hline Adenocarcinoma & 14 & 4 & \\
\hline Adenosquamous & 3 & 8 & \\
\hline Mixed & 3 & - & \\
\hline Differentiation & & & 0.83 \\
\hline Well & 11 & 4 & \\
\hline Moderate & 18 & 10 & \\
\hline Poor & 10 & 5 & \\
\hline Inflammatory cell radiation & & & 0.47 \\
\hline Mild & 11 & 4 & \\
\hline Moderate & 14 & 10 & \\
\hline Severe & 14 & 5 & \\
\hline Parametrial invasion & & & 0.14 \\
\hline$(+)$ & 3 & 4 & \\
\hline$(-)$ & 36 & 15 & \\
\hline Lymph vascular permeation & & & 0.13 \\
\hline$(+)$ & 9 & 8 & \\
\hline$(-)$ & 30 & 11 & \\
\hline $\begin{array}{l}\text { Invasion to the margin of } \\
\text { vagina }\end{array}$ & & & 0.98 \\
\hline$(+)$ & 2 & 1 & \\
\hline$(-)$ & 37 & 18 & \\
\hline Invasion to endometrium & & & 0.19 \\
\hline$(+)$ & 1 & 2 & \\
\hline$(-)$ & 38 & 17 & \\
\hline Lymph node metastasis & & & 0.0004 \\
\hline$(+)$ & 3 & 9 & \\
\hline$(-)$ & 36 & 10 & \\
\hline The depth of stromal invasion & & & 0.02 \\
\hline$<5 \mathrm{~mm}$ & 12 & 1 & \\
\hline$>5 \mathrm{~mm}$ & 27 & 18 & \\
\hline
\end{tabular}

\section{Lymphnode metastasis}

Nine $(75 \%)$ out of 12 cases with lymph node metastasis had recurence within 24 months, and 2 more cases in the $30^{\text {th }}$ and $31^{\text {st }}$ month. The rest 1 case was well controlled until the 43 months of follow up.

\section{Stromal invasion}

In the group of patients with $<5 \mathrm{~mm}$ stromal invasion, 1 patient suffered from distant metastasis in the inguinal \& coli lymph node 4 months after the operation. This case did not received adjuvant therapy because there was no risk factor.

\section{Adjuvant therapy}

There were only 58 cases which fulfilled the study criteria. From these 58 cases, there were 6 recurrent cases out of 20 cases receiving adjuvant radiotherapy, 4 recurrent cases out of 10 cases receiving adjuvant chemoradiation, 2 recurrent cases out of 3 cases receiving adjuvant chemotherapy, and 7 recurrent cases out of 25 cases without adjuvant therapy.

After the 24 months follow up, there was 1 more recurrent case in the adjuvant chemoradiation group which occurred in the $31^{\text {st }}$ month post operatively. The rest 5 cases in that group with no lymph node metastasis were well controlled until 87 months of follow up.

The risk factor (in 4 out of 6 recurrent cases receiving adjuvant radiotherapy, and in 3 out of 4 recurrent cases receiving adjuvant chemoradiation) was lymph node metastasis. However, the recurrent cases with adjuvant chemotherapy showed no lymph node metastasis.

The result of multivariate analysis was shown in Table 2.

Table 2. Multivariate analysis of factors in relation to the recurrence. ${ }^{*}$

\begin{tabular}{|c|c|c|c|}
\hline & $\begin{array}{l}\text { Number of } \\
\text { recurrence }\end{array}$ & $\begin{array}{c}\text { Number of } \\
\text { cases }\end{array}$ & $P$ Value \\
\hline Stage & & & 0.27 \\
\hline IB & 18 & 47 & \\
\hline IIA & 1 & 11 & \\
\hline Invasion to endometrium & & & 0.52 \\
\hline$(+)$ & 2 & 3 & \\
\hline$(-)$ & 17 & 55 & \\
\hline Lymph vascular permeation & & & 0.57 \\
\hline$(+)$ & 8 & 17 & \\
\hline$(-)$ & 11 & 41 & \\
\hline Lymph node metastasis & & & 0.004 \\
\hline$(+)$ & 9 & 12 & \\
\hline$(-)$ & 10 & 46 & \\
\hline Parametrial invasion & & & 0.42 \\
\hline$(+)$ & 4 & 7 & \\
\hline$(-)$ & 15 & 51 & \\
\hline The depth of stromal invasion & & & 0.30 \\
\hline$<5 \mathrm{~mm}$ & 1 & 13 & \\
\hline$>5 \mathrm{~mm}$ & 18 & 45 & \\
\hline Histology & & & 0.72 \\
\hline Squamous & 7 & 26 & \\
\hline Adenocarcinoma & 4 & 18 & \\
\hline Adenosquamous & 8 & 11 & \\
\hline Mixed & - & 3 & \\
\hline
\end{tabular}

* Analysis was done on data that showed $P$ value of $<0.2$ on bivariate analysis 


\section{DISCUSSION}

The mean of the patients age in this study was 38.8 years old and the median was 38 years old, which were younger than those in other studies i.e. 43.5 - 54 years old. It was also not older than those patients with adenocarcinoma, whose youngest age was 37.5 years old. ${ }^{9,14-17}$

There were 21 (30.8\%) recurrent cases out of 68 cases in the 2 years post surgery evaluation. The rest 26 cases were lost in follow up. If we estimate about $80 \%$ of the recurrences occurred within the first 2 years, there will be $38.5 \%$ recurrent cases within 5 years. This number is quite high compared to those reported by other workers. It is a pity that up to now there is no effective treatment to deal with these recurrences. This high recurrent rate was not only affected by the histopathologic factors, but also the inadequacy in understanding the disease that made the patient refused the adjuvant therapy.

In this study, the adenocarcinoma cases tended to have recurrence, 8 out of 11 cases had recurrence within the first 2 years. No recurrence was observed in the 3 cases with mixed histopathologic type. Therefore, the histopathologic type between adenosquamous carcinoma and mixed adenocarcinoma with squamous cell carcinoma need to be differentiated. Patients with risk factors i.e parametrial invasion, invasion to the margin of vagina incision, and/or invasion to endometrium responded well to adjuvant radiotherapy. Lymph node metastasis played an important role in the recurrence in this study. Nine (75\%) out of the 12 cases with lymph node metastasis had recurrence within the first 2 years and it becomes $11(91.6 \%)$ in the $31^{\text {st }}$ month. Ten out of these 11 recurrent cases received either adjuvant radiotherapy or adjuvant chemoradiation. In the group without lymph node metastasis, there were only $10(21.7 \%)$ out of 46 cases who had recurrence. Other studies even reported a smaller recurrent number.

Distant recurrence were found in 8 out of the 11 recurrent cases with lymph node metastasis. Four of the distant recurrent cases received adjuvant chemoradiation. Chemoradiation (MMC 5FU) was not effective to patient with distant metastasis. The deep of stromal invasion also played an important role in the recurrence. There was only 1 out of 13 cases with $<5 \mathrm{~mm}$ stromal invasion who had recurrence, while $2 / 3$ of the cases with $>5 \mathrm{~mm}$ stromal invasion had recurrence.
Radiation is chosen as the adjuvant therapy for high risk cases. However, this modality is unable to prevent the recurrence of disease $100 \%$. In general, fatality was the end in the recurrent cases. Some workers attempted to modify the adjuvant radiotherapy in combination with chemotherapy. Zanetta $\mathrm{G}$ et al reported the adjuvant chemoradiation using vincristine, bleomycin, mitomycin $\mathrm{C}$ and cisplatin for 28 cases with lymph node metastasis, parametrial invasion and vascular permeation..$^{13}$ The cases were followed up to 70 months; no recurrence in 15 cases; 2 patients quitted adjuvant therapy because of the complication. However, studies from other workers showed there was no effect of adjuvant chemoradiation to the recurrence and survival rate. ${ }^{18,19}$

In this study, the adjuvant radiation and the adjuvant chemoradiation (MMC $+5 \mathrm{FU}$ ) showed no difference in the results. The adjuvant therapies were unable to prevent recurrences in cases with lymph node metastasis. In addition, the schedule of 5FU administration was quite complicated for the subeducated patients who came to Cipto Mangunkusumo Hospital, and would affect the compliance of patient.

The relation of the location of recurrence to the histopathologic type or adjuvant therapy was not further analyzed because the number of cases was small. However, there was a report which stated that the distant recurrence rate in the adjuvant chemotherapy group was smaller than those in the adjuvant radiotherapy group. ${ }^{4}$ Sardi et al reported that neoadjuvant PVB could reduce the central recurrence but not the distant recurrence. ${ }^{13}$

In conclusion, there were $30.8 \%$ recurrent cases within the first 2 years in the 68 radical hysterectomies cases done in Cipto Mangunkusumo Hospital, between January 1992 and December 1995. Adenosquamous carcinoma tended to have recurrence, and almost all of the cases with lymph node metastasis had recurrence. Distant recurrence tended to occur in those cases, and adjuvant chemoradiation was unable to prevent it. However, cases with $<5 \mathrm{~mm}$ stromal invasion seldom had recurrence.

\section{REFERENCES}

1. Comerci G, Bolger S, Flanneelly G, Maini M, Lopes de Baros A, Monaghan JM. Prognostic factors in surgically treated stage IB - IIA carcinoma of the cervix with negative lymph node. Int J Gynecol Cancer 1988; 8:23-6. 
2. Eifel PJ, Berek JS, Thigpen JT. Cancer of the cervix, vagina and vulva. In: de Vita VT, Hellman S, Rosenberg SA. Cancer principles \& Practice of oncology. $5^{\text {th }}$ ed. vol. 1. Philadelphia: Lippincott - Raven; 1997. p. 1433-56.

3. Gerdin E, Cnattingius S, Johnson P, Pettersson B. Prognostic factors and relapse patterns in early stage cervical carsinoma after brachytherapy and radical hysterectomy. Gynecol Oncol 1994; 53:314-9.

4. Iwasaka T, Kamura T, Yokoyama M, Matsuo N, Nakano $H$, Sugimori $H$. Adjuvant chemotherapy after radical hysterectomy for cervical carsinoma : A comparison with effects of adjuvant radiotherapy. Obstet Gynecol; 1998: 91, 977-81.

5. Kamura T, Tsukamoto N, Tsuruchi, N Saito, $\mathrm{T}$ Matsuyama T, Akazawa $\mathrm{K}$ et al. Multivariate analysis of the histopathologic prognostic factors of cervical cancer in patients undergoing radical hysterectomy. Cancer 1992; 69:181-6.

6. Killackey MA, Boardman L, Carroll DS. Adjuvant chemotherapy and radiation in patients with poor prognostic stage IB/IIA cervical cancer. Gynecol Oncol 1993;49:377-9.

7. Lai CH, Hong JH, Hsueh $\mathrm{S}, \mathrm{Ng} \mathrm{KK}$, Chang TC, Tseng CJ et al. Preoperative prognostic variables and the impact of postoperative adjuvant therapy on the out come of stage IB or IIA cervical carsinoma patient with or without pelvic lymph node metastases. Cancer 1999; 85:1537-46.

8. Landoni F, Maneo A, Colombo A, Placa F, Milani R, Perego $\mathbf{P}$ et al. Randomized study of radical surgery versus radiotherapy for stage IB - IIA cervical cancer. Lancet $1997 ; 350: 535-40$.

9. Samlal RAK, van der Velden J, Schilthuis MS, Gonzalez DG, Kate FJW, Hart AAM et al. Identification of high risk groups among node positive patients with stage IA and IIA cervical carsinoma. Gynecol Oncol 1997; 64: 463-7.

10. Sardi JE, Giaroli A, Sananes C, Ferriera M, Soderini A, Bermudez A et al. Long term follow up of the first randomized trial using neoadjuvant chemotherapy in stage
IB squamous carsinoma of the cervix: The final results. Gynecol Oncol 1997; 67:61-9.

11. Wang CJ, Lai CH, Huang HJ, Honh JH, Chou HH, Huang $\mathrm{KG}$ et al. Recurrent cervical carsinoma after primary radical surgery. Am J Obstet Gynecol 1999; 181:518-24.

12. Wharton JT. Neoplasm of the cervix. In: Holland JF (ed) Cancer Medicine. $4^{\text {th }}$ ed. vol. 2. Baltimore: William \& Wilkins; 1997. p. 2227-61.

13. Zanetta G, Colombo A, Milani R, Placa F, Mangioni C. Long term results of sequential postoperative treatment with vincristine, bleomicyn, mitomicyn C, cis-stage IBIIA. Int J Gynecol Cancer 1995; 5:40-4.

14. Sevin BU, Nadji M, Lampe B, Lu Y, Hilsenbeck S, Koechli OR et al. Prognostic factors of early stage cervical cancer treated by radical hysterectomy. Cancer 1995; 76:1978-86.

15. Takesima N, Katase K, Hirai Y, Yamawaki T, Yamauchi $\mathrm{K}$, Hasumi K. Prognostic value of peritoneal cytology in patients with carsinoma of the uterine cervix. Gynecol Oncol 1997; 64:136-40.

16. Waldenstrom AC, Horvath G. Survival of patients with adenocarsinoma of the uterine cervix in western Sweden. Int J Gynecol Cancer 1999; 9:18-23.

17. Yanti A, Purdadi S, Sjahrul S. Kejadian residif pasca histerektomi radikal pada penderita adenokarsinoma serviks uteri stadium IB - IIA. Maj Obstet Ginekol Indones $1998 ; 22: 183-9$.

18. Lai CH, Hsueh S, Hong JH, Chang TC, Tseng CJ, Chou $\mathrm{HH}$ et al. Are adenocarsinomas different from squamous carsinomas in stage IB and II cervical cancer patients undergoing primary radical surgery? Int J Gynecol Cancer 1999; 9:28-36.

19. Monk BJ, Cha DS, Walker JL, Burger RA, Ramsinghanı NS, Manetta A et al. Extent of disease as an indication for pelvic radiation following radical hysterectomy and bilateral pelvic lymph node dissection in the treatment of stage IB and IIA cervical carsinoma. Gynecol Oncol $1994 ; 54: 4-9$. 